\title{
Sistematik Riskin Hisse Senedi Getirisine Etkisi: Borsa İstanbul Örneği
}

\author{
Faruk DAYI*
}

\section{ÖZ}

Sistematik risk, hisse senetlerinin getirisini olumsuz yönde etkileyebilmektedir. Sistematik riskin tamamen ortadan kaldırılması mümkün değildir. Yatırımcılar portföyü çeşitlendirerek sistematik olmayan riski azaltmakta ve portföyün toplam riskini düşürebilmektedir. $\mathrm{Bu}$ nedenlerden dolayı, sistematik risk yatırım kararlarında oldukça önemlidir. Bu amaçla çalışmada sistematik riskin hisse senedi getirisi üzerindeki etkisinin incelenmesi amaçlanmıştır. Önceki çalıșmalarda mali tablo verileri ile beta katsayısının kullanıldığı görülmektedir. Önceki çalıșmalardan farklı olarak modelde hisse senedinin fiyatı, faiz oranı enflasyon oran1, döviz kuru, politik risk endeksi, piyasa risk değişkeni olarak BIST 100 endeksi modelde yer almaktadır. Borsa İstanbul imalat sanayi sektöründe faaliyet gösteren 174 şirketin 2009-2017 dönemi verileri kullanılmıştır. Uygulama da panel veri yöntemi ile analiz yapılmıştır. Analiz sonucunda hisse senetlerinin getirisinin sistematik riskten etkilendiği tespit edilmiştir.

Anahtar Kelimeler: Portföy yönetimi, Sistematik risk, Panel veri, Hisse senedi getirisi, Borsa İstanbul

JEL Sınıflandırması: G11, G32, C23

\section{Impact of Systematic Risk on Stock Return: An Application on Istanbul Stock Exchange}

\begin{abstract}
Systematic risk affects adversely the returns of stocks. It is not possible to eliminate all of systematic risk. Investors want to reduce the non-systemic risk by diversifying the portfolio, thus reducing the total portfolio risk. For this reason, systematic risk is very important in investment decisions. The aim of this study is to examine the effect of systematic risk on stock return. They are seen that the financial table data and beta coefficient of the companies are frequently used in the previous literature. Unlike previous studies, the model has got BIST 100 index variables as model price, interest rate inflation rate, exchange rate, political risk index, market risk variable. 2009-2017 period data of the 174 companies operating in the Borsa İstanbul manufacturing industry sector were used in analysis. In the implementation is used of the method of the panel data. As a result of the analysis, it was determined that the return of the stocks was affected by the systematic risk.
\end{abstract}

Keywords: Portfolio management, Systematic risk, Panel data, Stock return, Istanbul Stock Exchange

JEL Classification: G11, G32, C23

Geliş Tarihi / Received: 08.01.2019 Kabul Tarihi / Accepted: 11.07.2019

\footnotetext{
* Dr. Öğr. Üyesi, Kastamonu Üniversitesi, İİBF, İşletme Bölümü, faruk_dayi@hotmail.com, ORCID: 0000-00030903-1500.
} 


\section{GİRİŞ}

Hisse senetlerinin getirileri ile portföy riski arasında pozitif yönlü bir ilişki vardır (Fama \& MacBeth, 1973: 633). Hisse senedinin getirisinin yükselmesi riski artırmakta; getiri azaldıkça da portföy riski düşmektedir. Yatırımcıların hisse senedinden bekledikleri verim, dolaylı olarak şirketin sermaye maliyetini oluşturmaktadır. Dolayısıyla sistematik risk şirketin sermaye maliyetini ve piyasa değerini etkilemektedir (Copeland, Koller, \& Murrin, 2000: 202). Yatırımcılar şirketin piyasa değeri ile gerçek değerini karşılaştırarak portföylerini oluşturmaktadır. Dolayısıyla yatırımcıların potansiyeli olmayan hisse senetlerini satın almaları rasyonel olmayacağından portföy riskini yükseltebilmektedir. $\mathrm{Bu}$ nedenle yatırımcılar maruz kaldıkları riski düşürerek daha yüksek getiri elde etmek istediklerinden, portföyden beklenen verimin elde edilebilmesi toplam riskin düşürülmesiyle mümkün olabilmektedir. $\mathrm{Bu}$ nedenle yatırımcılar portföydeki hisse senetlerini çeşitlendirerek hem portföyün toplam riskini düşürmekte hem de daha yüksek getiri elde edeceği hisse senetlerinden portföylerini oluşturmaktadır. Böylece oluşturulan portföyün riski, hisse senetlerinin risklerinin toplamından daha düşük olmaktadır.

Belirsizlik arttıç̧a hisse senetlerinin riski de yükselmektedir. Özelliklede küçük şirketlerin çalışan sayısı, gelirleri ve varlıkları az olduğundan, bu şirketlerin hisse senetlerinin getirileri, büyük şirketlere göre daha az olabilmektedir (Zhang, 2006: 108-111). Bu nedenle yatırımcılar küçük şirketlerin hisse senetlerini pek tercih etmedikleri ifade edilmektedir (Banz, 1981: 16-17). Çünkü yatırımcıların hisse senedi satın alma kararlarında muhasebe verilerinin de önemli bir yeri olduğu görülmektedir (Beaver, Kettler, \& Scholes, 1970: 769). Bu durumda yatırımcılar yeni kurulmuş veya yeterli düzeyde verisi olmayan şirketlerin hisse senedini riskli bulabilir. Hisse senetlerinin verilerinin yeterli düzeyde olmayışı diğer bir ifadeyle yeni kurulmuş bir şirketin geçmişe sahi olmayışı yatırımcılar için belirsizliğe neden olabilmektedir. Belirsizlik ise yatırımcılar için önemli bir risk oluşturabilmektedir.

Yatırımcılar portföy riskini çeşitlendirmeyle azaltmak istese de, bazı risklere müdahale etmesi mümkün değildir. Çünkü portföy riski sistematik risk ve sistematik olmayan riskin toplamından oluşmaktadır. Sistematik risk, makroekonomik faktörlerden doğrudan etkilenmektedir (II, 1976: 187). Sistematik risk, şirketin kontrolünde olmadığından tamamen yok edilmesi mümkün değildir. Dolayısıyla yatırımcının bu riske herhangi bir müdahalesi söz konusu olmayıp, kaçınması mümkün değildir. Literatürdeki birçok çalışmada sistematik risk beta katsayısı olarak ifade edilmektedir. Beta katsayısı firmalar için değil genellikle portföy için hesaplanmaktadır (Kaya, 2011: 119). Çünkü portföy riskinin hesaplanmasında beta katsayıs1 kullanılmaktadır. Sistematik olmayan risk ise şirketin kendi faaliyetlerinden kaynaklanan, etkin bir risk yönetimiyle azaltılabilmektedir. Böylece portföydeki hisse senetlerinin sistematik olmayan risklerinin azalmasıyla, portföyün toplam riski de azalmaktadır. Yatırımcıların portföylerini oluştururken sistematik ve sistematik olmayan risk unsurlarını birlikte değerlendirerek yatırım kararı almaları önerilmektedir.

Gelişmiş ve gelişmekte olan menkul kıymetler borsalarında sistematik ve sistematik olmayan riskler farklılık göstermektedir. Örneğin ekonomik gelişmişlik düzeylerine bağlı olarak menkul kıymet borsaları arasındaki farklılıklar azaltılabilir (Demir, 2010: 83). Çünkü sistematik risk, siyasi ve ekonomik birçok faktörden etkilenmektedir. Örneğin vergi oranları ve petrol fiyatlarındaki değişim sistematik riski artırabilmektedir (Horne \& Wachowic, 2008: 105). Ülkelerin siyasi, ekonomik ve finansal sistemlerindeki farklılıklardan dolayı politik, enflasyon oranı, faiz oranı ve döviz kuru riskleri farklılık gösterebilmektedir. $\mathrm{Bu}$ nedenle gelişmiş ekonomilerdeki sistematik riskin düzeyi, gelişmekte olan ekonomilerdeki sistematik riske göre daha az düzeyde olabilir. Özelliklede küresel sermaye ve finans piyasasında yaşanan gelişmeler sistematik riski tetikleyebilmektedir. Örneğin Amerikan Merkez Bankası'nın (FED) alacağı faiz 
artırma kararı, çeşitli riskleri tetikleyerek ulusal sermaye piyasalarının olumsuz yönde etkilemesine neden olabilir. Sistematik riskin ölçülmesinde çeşitli yöntemler kullanılmaktadır. "Sermaye Varlıklarını Fiyatlandırma Modeli" literatürde en yayın kullanılan yöntemlerden biridir (Karadeniz, Kandır, \& İskenderoğlu, 2015: 191). Yatırımcılar portföy oluştururken Sermaye Varlıklarını Fiyatlandırma Modelinden yararlanmakta, ödünç alınan risksiz faiz oranı ile piyasa portföyü veya ödünç verenlerin faiz oranı ile piyasa portföyü kombinasyonlarından birini tercih etmektedir (Hamada, 1972: 435). Sistematik riskin veya beta katsayısının ölçülmesiyle, hisse senedinin değerini etkileyecek muhtemel riskler önceden tahmin edilebilmektedir (Bowman, 1979: 617). Bu nedenle sistematik risk ile hisse senedi getirisi arasındaki ilişkisinin incelenmesi gerekmektedir.

Borsa İstanbul'da işlem gören imalat sanayi şirketlerinin hisse senetlerinin getirilerine etki eden sistematik risk unsurlarını çalışmada incelemiştir. Şirketlerin hisse senetlerinin kapanış fiyatları ile çeşitli makroekonomik değişkenlerden oluşan model geliştirilmiştir. Uygulamada 2009-2017 dönemi verileri kullanılarak analiz yapılmış ve bulgular değerlendirilmiştir.

\section{LITERATÜR}

Sistematik riskin ölçülmesiyle ilgili ilk çalışma modern portföy yönetim teorisini ileri süren Markowitz (1952) tarafından yapılmış olup, Sharpe (1964), Lintner (1965) ve Mossin (1966) Sermaye Varlıklarını Fiyatlandırma Modelini kullanarak sistematik risk ile portföy yönetimi üzerine çeşitli çalışmalar yapmışlardır (Ho, Xu, \& Yap, 2004: 395). Portföyde yer alan birçok menkul kıymetin getirisi, piyasa getirisiyle aynı yönde hareket ettiğinden farklılaştırma yöntemiyle tamamen ortadan kaldırmak mümkün değildir (Okka, 2015: 407). Bazı riskler şirketin kendisinden kaynaklanmayıp makroekonomik göstergelerden kaynaklandığından, yatırımcıların bu riskleri elimine etmesi veya ortadan kaldırması pek mümkün değildir. Çünkü şirketin kendisinden kaynaklanmayan sistematik risk çeşitlendirmeyle yok edilemez (Karan, 2004: 157). Ancak portföydeki menkul kıymetler arasında mükemmel bir korelasyon ilişkisi olmadığında, portföydeki menkul kıymetler farklılaştırılarak portföyün toplam riskinin azaltılması mümkündür (Okka, 2015: 407). Menkul kıymetlerin çeşitlendirilmesi sonucunda ilave edilen her bir menkul kıymetin standart sapması öncekilerden farklı olduğundan, portföyün toplam standart sapması ortalaması, önceki portföye göre daha düşük olacağından portföyün toplam riski düşmektedir (Brigham \& Houston, 2014: 269). Şirketin kendisinden kaynaklanmayan sistematik risk dışında, şirketin kendisinden kaynaklanan çeşitli riskler vardır ki bunlar sistematik olmayan risk olarak ifade edilmektedir. Sistematik olmayan risk farklılaştırmayla ortadan kaldırılabilmektedir. Dolayısıyla literatürde portföy riski, sistematik risk ve sistematik olmayan risk olarak ikiye ayrılmaktadır (Okka, 2009: 233).

Sistematik risk piyasayı etkileyen faktörlerden kaynaklanan, piyasadaki veya borsadaki tüm menkul kıymetleri aynı anda ve aynı yönde etkileyen risktir. Sistematik risk, tüm finansal piyasaları ve menkul kıymetleri aynı anda etkilemektedir (Oral \& Y1lmaz, 2017: 194). Şirketler varlıklarını sürdürdükleri sürece ülkeden kaynaklanan bu riski azaltmaları, ortadan kaldırmaları veya kaçınmaları mümkün değildir. Sistematik risk literatürde farklı kategorilerde sınıflandırılsa da genel olarak faiz oranı riski, enflasyon riski, piyasa riski, döviz kuru riski ve politik risk olmak üzere 5 kategoride incelenmektedir.

Faiz oranı riski, piyasa faiz oranındaki değişimden kaynaklanmaktadır. Faiz oranlarındaki görülen değişim, tüm finansal araçları etkilediğinden, hisse senetlerinin fiyatları da etkilenmektedir (Aksoy \& Tanrı̈ven, 2007: 37). Faiz oranındaki yükseliş, hisse senetlerinin elden çıkarılıp, hazine bonosu, devlet tahvili gibi faize dayalı menkul kıymetlere yönelimi artırabilir. Çünkü faiz oranlarındaki yükseliş, yatırımcıların risksiz getiri beklentilerini artırmakta ve faize dayalı finansal araçlara olan talebi de artırabilmektedir. Bunun yanı sıra kısa veya uzun 
vadeli faiz oranları değişim gösterdiğinde, dolayısıyla faiz oranı riskini de etkilemektedir (Aksoy \& Tanriöven, 2007: 37).

Piyasa riski, piyasadaki fiyat dalgalanmalarından kaynaklanan risktir (Ercan \& Ban, 2008: 178). Hisse senetlerinin fiyatlarındaki değişimin rasyonel bir nedeni olabileceği gibi herhangi bir neden olmadan da değişim gösterebilmektedir. Piyasa riski, piyasada yaşanan fiyat dalgalanmaları sonucunda portföyde meydana gelen fiyat düşüklüklerinin gerçekleşme ihtimalini ifade etmektedir (Usta \& Demireli, 2010: 27). Bu durumda piyasada meydana gelen olumsuz etkiler, hisse senetlerinin fiyatlarını negatif yönde etkilemekte ve hisse senetlerinin fiyatı düşmekte, dolayısıyla piyasa değeri de düşmektedir.

Döviz kuru riski, ulusal para biriminin yabancı para birimi karşısında değer kazanma veya kaybetme olasılı̆̆ıdır. Farklı para birimlerinden oluşan portföyler, döviz kurundaki negatif yönlü hareketler sonucunda portföyün ulusal para biriminden değerinin düşmesine neden olabilmektedir (Ceylan \& Korkmaz, 2004: 455). Döviz kurundaki değişim, faiz oranı üzerinde doğrudan etkili olduğundan, hisse senetlerinin fiyatını da etkilemektedir. Döviz kurundaki hızlı yükselişler, menkul kıymet yatırımcılarının sermaye piyasasından para piyasasına doğru yönelmesine neden olabilmektedir. Döviz kurundaki değişim sadece finansal piyasaları değil, emtia piyasalarını da etkilemektedir. Döviz kurundaki artış emtianın fiyatını düşüreceğinden ihracat artabilmekte, ancak ithalat ağırlıklı ekonomilerde ise emtianın fiyatı yükseleceğinden halkın alım gücünü düşüreceğinden şirketlerin ithalat tutarının düşmesine neden olabilmektedir (Doğanay, 2016: 151). Yatırımcılar, şirketler ve hatta devletler döviz kuru riskine karşı vadeli işlemler piyasasında pozisyon alarak riski minimize edebilirler.

Siyasi risk, devlet ve hükümet yönetiminden kaynaklanmaktadır. Menkul kıymet borsalarının doğrudan etkilendiği, hisse senetlerinin satış baskısıyla karşılaşması durumunda fiyatların düşmesine neden olduğu önemli bir sistematik risk türüdür. Ulusal ve uluslararası siyasi gelişmeler para ve sermaye piyasasını olumsuz yönde etkileyebilmektedir. Siyasi risk, hükümet değişikliği, darbe, iş savaş gibi çeşitli siyasi olayların meydana gelme olasılığı olarak tanımlanmaktadır (Kaya, Güngör, \& Özçomak, 2014: 74). Şirketlerin el değiştirmesi, devletleştirilmesi veya özelleştirilmesi gibi çeşitli siyasi olaylarda şirketin piyasa değeri üzerinde olumsuz etkiler meydana getirebilmektedir (Çam, 2010: 9-10). Siyasi risk her ülkede farklilık gösterebilmekte ancak Amerika Birleşik Devletleri gibi bazı ülkelerde alınan siyasi kararlar tüm sermaye piyasalarını doğrudan etkileyebilmektedir. Hisse senetleri en riskli yatırım aracı olduğundan, menkul kıymetler borsaları siyasi karar organlarının kararlarına karşı kırılgan bir yapıya sahiptirler (Tükenmez \& Kutay, 2016: 633). Bu nedenle yaşanan önemli siyasi gelişmeler hisse senetlerinin fiyatlarında dalgalanmalara neden olabilmektedir. Yatırımcılar siyasi riskten korunmak için genellikle gelişmiş ülkelerin menkul kıymetler borsalarına yöneldikleri görülmektedir.

Enflasyon, fiyatlar genel düzeyindeki yükselişin, paranın satın alma gücünde neden olduğu düşüş olarak ifade edilmektedir. Fiyatlar sabitken, maliyetlerin artmasıyla şirketlerin karı veya karlılığı azalabilmekte, hisse senedinden beklenen verim alınamadığında ise hisse senedinin fiyatı olumsuz yönde etkilenebilmektedir. Enflasyon ile hisse senedi arasında negatif yönlü ilişkinin olduğu literatürde yapılan çalışmalarda ifade edilmektedir (Gümüş, 2018: 8-9). Enflasyon oranının artmasıyla diğer etkenler sabitken, yatırımcıların hisse senedini satın alma gücü azalabilmektedir. Enflasyon oranının artması yatırımcıların beklediği reel getirinin azalmasına neden olabilmektedir (Usta \& Demireli, 2010: 27). Yatırımcı hisse senedini sattığı tarihteki enflasyon oranı, hisse senedini satın aldığı tarihteki enflasyon oranından yüksek olursa, yatırımcının beklediği verim azalabilmektedir. Bu durumda enflasyondaki yükseliş yatırımcı için bir risk oluşturmaktadır. Bu nedenle yatırımcılar enflasyon oranının yükselmediği piyasalarda yatırım yaparak enflasyon riskini azaltabilirler. 


\section{LITERATÜR TARAMASI}

Bu kısımda sistematik risk ve sistematik olmayan riskin hisse senedi fiyatı veya getirisi üzerine etkisini inceleyen çalışmalara yer verilmiştir.

Gümüş (2018) BİST sınai sektöründe yer alan 16 alt sektörün sistematik ve sistematik olmayan risklerini Sermaye Varlıklarını Fiyatlandırma Modeli ile incelemiştir. 2002-2016 dönemi üçer aylık verileri kullanılmıştır. Beta, standart sapma, makroekonomik veriler, finansal rasyolar ile regresyon ve zaman serisi analizi yapılmıştır. İletişim, turizm, ulaştırma ve ticaret sektöründe enflasyonun sistematik risk üzerinde etkisi olduğu ifade edilmiştir. Oral ve Yılmaz (2017) sistematik risk olan politik risk ile sistematik olmayan risk olan finansal riskin BIST Sınai endeksi üzerine etkisinin varlığını incelemiştir. Uygulamada ICRG (International Counrty Risk Guide) olarak ifade edilen politik risk endeksi ile finansal risk endeksleri ile BIST sinai endeks verilerinden bir model oluşturulmuştur. 1992-2014 yılları verileri sınır testi ile analiz edilmiştir. Analiz sonucuna göre Borsa İstanbul Sınai Endeksi ile politik riskin arasında kısa ve uzun dönemli ilişkinin olduğu tespit edilmiştir. Tepeli (2017) halka açı olmayan anonim şirketlerde sistematik risk ölçütü beta katsayısının turizm sektöründe etkisini araştırmıştır. Halka açık olan 9 şirket ile halka açık olmayan bir şirketin beta katsayısını incelemiştir. 2011-2015 dönemi mali tablolarından elde edilen rasyo verileri ile beta katyasısı değişkenlerini panel veri yönteminde analiz etmiştir. Halka açık olmayan turizm şirketlerinin beta katsayısını 0,676 olarak tespit etmiştir. Dolayısıyla endeks \%10 arttı̆̆ında hisse senedi \%6,76 değer kazanmakta, tam tersi durumda ise değer kaybetmektedir. Karadeniz vd. (2015) Borsa İstanbulda işlem gören turizm şirketlerinin sistematik risklerinin nedenlerini incelemiştir. 8 şirketin 2003-2012 dönemi finansal verileri kullanılarak Genişletilmiş Momentler Yöntemiyle analiz yapılmıştır. Sistematik riskin; aktif büyüklük ile pozitif yönde, aktif devir hızıyla negatif yönde ilişkisi olduğu tespit edilmiştir. Asit test oranı, kaldıraç oranı, aktif karlılık oranı ile sistematik risk arasında anlamlı bir ilişki bulunamamıştır. Arslan (2013) sistematik riskin bileşenlerini incelemiştir. Borsada işlem gören 6 turizm şirketinin 1997-2011 dönemine ait verileri panel veri yöntemiyle analiz yapılmıştır. Modelde likidite, borç oranı, faaliyet etkinliği, karlılık, firma büyüklüğü ve büyüme değişkenleri yer almaktadır. Büyüme oranının sistematik riskle negatif yönde ilişkisi olduğu, diğer değişkenlerin istatistiksel anlamlılığı olmadığı tespit edilmiştir. Cav (2011) sistematik riskin konaklama işletmelerinin karlılık üzerine etkisini incelemiştir. Uygulamada Marmaris Altınyunus Turistik Tesisler A.Ş.'nin 7 yıllık karlılık oranları ve beta katsayısı değişkenleri kullanılarak regresyon analizi yapmıştır. Karlılık oranlarının \%16'lık kısmının sistematik risk ile açıklandığ tespit edilmiştir.

Tükenmez ve Kutay (2016) gelişmekte olan ülkelerden Türkiye ile Arjantin ülkelerinin ülke risklerinin hisse senedi fiyatı üzerinde etkisinin varlığını incelemişlerdir. ICRG endeksi, hisse senedi fiyatı ve diğer değişkenlerin 1996:10 ile 2013:12 verileri modelde kullanılmıştır. Uygulamada Regresyon, Eşbütünleşme testi ve Granger nedensellik testi yapılmıştır. Finansal ve politik risk endeksinin ülkemiz borsa endeksi ile ilişkisi olduğu tespit edilmiştir. Finansal risk derecesi ve borsa endeksi arasında çift yönlü nedensellik ilişkisi saptanmıştır. Ülkemizde finansal risk ve politik riskin hisse senedi fiyatını olumsuz yönde etkilediği ifade edilmiştir. Uğurlu vd. (2016) sistematik olmayan riski azaltacak doğrusal programlama modeli önerilmiştir. Çalışmanın amacı portföy yönetiminde standart sapma yerine mutlak sapmayı dikkate alan bir model geliştirmektir. BIST 100 endeksindeki 83 hisse senetinin verileri doğrusal programlama yönteminde kullanılmıştır. Markowitz'in ortalama-varyans modeli büyük portföyleri oluşturmakta başarılı olmadığı ifade edilmiştir. Çalışmanın sonucunda farklı endüstri kollarından hisse senetlerinden portföy oluşturularak sistematik olmayan riskin azalabileceği ifade edilmiştir. Kara (2016) Borsa İstanbul'da işlem gören şirketlerin muhasebe verileri ile sistematik risk arasındaki ilşikiyi ncelemektedir. Uygulamada 120 şirketin 2012-2015 dönemi 27 finansal oranı ile çoklu regresyon analizi yapılmıştır. KYYK/Toplam Borç, Maddi Duran Varlık/Uzun Vadeli 
Borçlar, Finansman oranı, Stok Devir Hızı, Aktif Karlı1ık Oranı, Faaliyet Karlılık Oranı, Hisse Başına Kar değişkenleri ile sistematik risk arasında anlamlı bir ilişkinin olduğu ifade edilmiştir.

Bozkurt (2014), iflas olasıllı̆g ile sistematik risk arasındaki ilişkiyi incelemiştir. Borsa İstanbul'da işlem gören 168 şirketin 20.664 aylık getiri değişkeninden oluşan toplam 127.008 gözlem değeri ile şirketlerin finansal başarısızlıkları için Altman Z Modeli dahil 8 iflas modeli oluşturarak panel regresyon analizi yapmıştır.Şirketlerin iflas karlılığında ki yükseliş, sistematik riskin yükselttiği; Ohlson-O ve Springate-S modellerinin Borsa Istanbulda daha etkin oldukları tespit edilmiştir. Kaya vd. (2014) sistematik olmayan risklerden siyasi riskin hisse senedi fiyatı üzerine etkisini incelemiştir. Borsa İstanbul 100 endeksi ile siyasi risk endeksinin 1998-2012 dönemi aylık verileri kullanılarak regresyon, eş bütünleşme ve nedensellik testi analizleri yapılmıştır. Analiz sonucunda siyasi riskin endeksle uzun dönemli bir ilişkisi olduğu, siyasi risk endeksindeki değişimin borsa endeksini etkilediği ve iki değişken arasında negatif yönlü bir ilişkinin olduğu tespit edilmiştir. Kaderli vd. (2013) BIST 100 endeksinde meydana gelen değişimi, her bir sektörün beta katsayısı ile karşılaştırarak pazar getirileri ile risk arasındaki ilişkiyi incelemiştir. Pazar endeksi, sektör endeksine göre ortalama getiri, varyans ve standart sapma değişkenlerinin 2010-2012 dönemine ait 3 yıllık verileri modelde kullanılmıştır. Bankacılık, spor ve ulaştırma sektörlerinin en atak sektörler olduğu, bu sektörlerdeki hisse senetlerinin getirileri, pazar getirisinden daha yüksek bir oranda tepki verdiği tespit edilmiştir. Sistematik riski fazla olduğundan, bu sektörlerde enkdesin düşme eğilimi göstermesi durumunda yatırımcıların yatırım yapmaması tavsiye edilmektedir. Çam (2010) ülke riskiyle firma değeri arasındaki ilişkiyi İMKB 100 endeksinde sürekli işlem gören şirketlerin değeri üzerine etkisini incelemiştir. Şirketlerin 2000-2009 dönemi üçer aylik mali tablo verileri ile ICRG endeksi değişkenleri ile panel veri analizi yapılmıştır. Ekonomik, finansal ve sosyo-politik risk primlerinin firma değerini negatif yönde etkilediği ifade edilmiştir.

İskenderoğlu (2012), sistematik risk ölçütü olarak beta katsayısının hisse senedinin getirisi ile pazar getirisi arasındaki ilişkiyi gösterdiğini ifade etmektedir. Bu nedenle hisse senetlerinin sistematik risklerini değerlendirebilmek için beta katsayısını hesaplamış ve gelecekte değeri için öngörüde bulunmuştur. Uygulamada İMKB'de işlem gören 73 şirketin 2003-2011 dönemi verileri ile panel veri analizi yapılmıştır. Beta katsayısının rassal olmadığını tespit edilmiştir. Akıncı (2007) Finansal Varlık Fiyatlama Modelini kullanarak en küçük kareler yöntemiyle beta katsayısı tahmini yapmıştır. Çalışmada 1998-2005 dönemine ait iki ardış1k dörder yıldan oluşmak üzere 8 yıllık veri kullanılmıştır. Modelde 10 hisse senedinden oluşan portföy ile İMKB 100 endeksi değişkenleri yer almaktadır. Analiz sonucunda günlük getiri verileri kullanılarak yapılan tahminin, aylık verilerden daha anlamlı sonuçlar verdiği ifade edilmiştir. Tanrıöven ve Aksoy (2011) 1997-2008 yıllarında İMKB'de işlem gören şirketlerin muhasebe değişkenlerini kullanarak dengesiz panel veri analizi ile sistematik riskin varlığını incelemiştir. Satışlardaki büyümenin gıda ve teknoloji sektörleri haricinde tüm sektörlerde betay1 etkilediği, kaldıraç rasyosunun sadece metal sektörünü etkilediğini ve fiyat/kazanç oranı değiş̧keninin taş-toprak sektöründe etkili olduğu tespit edilmiştir. Ayrıca sektörler bazında etkili olan değişkenlerin birbirlerinden farklılık gösterdiği ifade edilmiştir.

Dalgıç (2011) İMKB 30 endeksinde yer alan 14 şirketten oluşan hipotetik portföyün riske maruz değerini, Sermaye Varlıklarını Fiyatlandırma Modeli ile sistematik risk ve sistematik olmayan risk olarak iki kategoriye ayırarak şirketlerin risk dağılımını incelemiştir. Uygulamada 01.01.2006-31.03.2011 dönemine ait günlük veriler kullanılarak, portföyün 1 ve 10 günlük getiri verilerine riskin etkisi tespit edilmiş, şirketlerin sistematik risk ve sistematik olmayan risklere göre yüzdelik dağılımları hesaplanmıştır. Analiz sonucunda örneklemdeki şirketlerin beta katsayıları pozitif olduğu tespit edilmiştir. Sistematik riski en yüksek olan şirketlerin bankacılık sektöründe faaliyet gösterdiği ifade edilmektedir. Usta ve Demirel (2010) İMKB' de oluşturdukları 3 şirketten oluşan portföyün 12.04.2007-01.12.2008 tarihleri arasındaki verileri kullanılarak getiri ve riski arasındaki ilişkiyi Finansal Varlıkları Fiyatlandırma Modeli 
ile incelemiştir. Uygulama kapsamındaki 3 hisse senedinin riskleri, piyasa riskinden arındırılarak, sistematik risk düzeyi incelenmiştir. Aynı sektörde faaliyet gösteren şirketlerin sistematik riskleri aynı olsa da, sistematik olmayan risklerin farklılık gösterdiği tespit edilmiştir. Poyraz (2011), sistematik riskin konaklama işletmelerinin karlılıkları üzerine etkisini değerlendirmek için İMKB'de işlem gören bir turizm şirketinin 2004-2010 dönemi mali tablo verilerinden elde edilen değişkenlerden oluşan modele korelasyon ve regresyon testleri yapılmıştır. Karlılık oranlarının \% 16 'lık kısmının sistematik risk faktörleri tarafından açıklandığı sonucuna ulaşılmıştır. Dolayısıyla sistematik risk unsurları karlı1ık oranları üzerinde \%16 oranında bir etkiye sahiptir.

Demir (2010) gelişmekte olan ülkelerin menkul kıymet borsalarındaki hisse senedi piyasalarının sistematik risk ile toplam risk düzeyini incelediği çalışmada, standart sapma, beta katsayısı ile MSCI (Morgan Stanley Capital International) endeksinin 2002-2009 dönemi verilerini kullanmıştır. Uygulamada istatistiksel bir yöntem kullanılmamış olup standart sapma ve beta katsayısı hesaplanarak analiz yapılmıştır. Çalışmanın sonucunda standart sapma ve beta katsayısı değişkenlerinin farklı dönemlerde farklılık gösterdiği ifade edilmiştir. Eryiğit ve Eryiğit (2009) sistematik riski etkileyebileceği düşünülen finansal oranlar kullanarak hisse senetlerinin riskliliklerini incelemiştir. Uygulamada İstanbul Menkul Kıymetler Borsasında işlem gören şirketlerin asit test oranı, borç/özkaynak oranı, özkaynak getiri oranı, aktif devir hızı ve savunma aralığı değişkenlerine ait 1995-2005 dönemi verileri panel regresyon analizinde kullanılmıştır. Analiz sonuçlarına göre asit test oranı, aktif devir hızı ve savunma aralığı ölçümü değişkenlerinin sistematik riski etkiledikleri tespit edilmiştir. Derindere ve Dizdarlar (2008), beta katsayısı ile hisse senedi getirisi arasındaki ilişkiyi inceleyerek sistematik riskin getiri üzerine etkisini değerlendirmiştir. Uygulamada İMKB 100 endeksinde yer alan 64 şirketin 2002-2006 dönemi verilerini Sermaye Varlıklarını Fiyatlama Modelini kullanarak T Testi ve ANOVA ile analiz etmiş̧tir. Getiri aralığı kısaldığında hesaplanan betaların düşme eğiliminde olduğu tespit edilmiştir. Ulusoy (2008), sistematik riskin finansal oranlar üzerindeki ilişkisini incelemiştir. 1994-2001 dönemine ait İMKB'de işlem gören 30 şirketin verisini çoklu regresyon analizinde kullanmıştır. Analiz sonucunda şirketlerin finansal rasyoları ile beta katsayısı arasında istatistiksel olarak anlamlı bir ilişkinin olmadığı tespit edilmiştir. Ayrıca yüksek korelasyon ilişkisinin varlı̆̆ modelin anlamlılık düzeyini olumlu ya da olumsuz etkileyebileceği belirtilmiştir. Yalçıner (2006), risk ve getiri arasındaki doğrusal ilişkiyi İstanbul Menkul Kıymetler Borsasında (IMKB) incelemiştir. Uygulamada borsada işlem gören tüm şirketlerin 2000-2004 dönemine ait 260 haftalık hisse senedi fiyat1, beta katsayıs1 ve risksiz faiz oranı verileri regresyon analizinde kullanılmıştır. Analiz sonucunda Sermaye Varlıklarını Fiyatlandırma Modelinin İMKB'de geçerli olmadığı ifade edilmiştir.

Tandelilin (1997) Jakarta Menkul Kıymetler Borsasında işlem gören hisse senetlerinin sistematik riskten etkilenip etkilenmediklerini incelemiştir. Uygulamada 60 şirketin 1990-1994 dönemine ait finansal oranları, enflasyon oranı, faiz oranı ve GSMH verileri kullanılmıștır. Çoklu regresyon yöntemiyle analiz yapılmıştır. Analiz sonuçlarında hisse senetlerinin sistematik riskten etkilendiği tespit edilmiştir. Chen ve Ramasamy (1989) gelişen sermaye piyasalarından Kuala Lumpur Menkul Kıymetler Borsasında işlem gören hisse senetlerinin sistematik risk düzeyleri ile şirketlerin muhasebe verilerinin arasındaki ilişkiyi incelemiştir. Uygulamada 76 şirketin mali tablo verileri kullanılarak korelasyon testi, faktör ve regresyon analizi yapılmıştır. Analiz sonucunda karlılık, faaliyet ve likidite oranlarının sistematik riskin önemli belirleyicilerinden olduğu, kaldıraç oranının ise sistematik riskten etkilenmediği tespit edilmiştir. Beaver ve Manegold (1975) New York Borsasında işlem gören 254 şirketin 1951-1969 dönemi verilerini kullanarak muhasebe ve pazar beta katsayısının sistematik riskle ilişkisini araştırmıştır. Analiz sonucunda muhasebe beta katsayısı ile portföy betası arasında istatistiksel açıdan anlamlı bir fark olduğu tespit edilmiştir. Hamada (1972) sistematik riskin borsada işlem gören şirketlerin sermaye yapısı üzerine etkisini incelemiştir. Uygulamada dönemi 304 hisse senedinin 1948-1967 
dönemi verileri (hisse senedi getirisi, getiri ortalaması ve getirilerin standart sapmas1) kullanılarak regresyon analizi sektörler ayrılarak yapılmıştır. Analiz sonucunda MM vergi kaldıraçlı sermaye maliyeti görüşüne göre hisse senetlerinin \%21-\%24 arasında sistematik riskten etkilendiği ifade edilmiştir.

\section{VERİ VE YÖNTEM}

Çalışmanın amacı sistematik riskin hisse senedi getirisi üzerindeki etkisini tespit etmektir. Literatürde yapılmış çalışmalarda Beta katsayısı, muhasebe verileri, çeşitli rasyolar, endeks getirileri kullanılarak sistematik riskin hisse senedi getirisi üzerindeki etkisi incelenmiştir. Literatürdeki çalışmalardan farklı olarak mikro veri kullanılmayıp, makroekonomik göstergeler ile analiz yapılmıştır. Sistematik riskin unsurları örneğin faiz oranı enflasyon oranı, döviz kuru gibi riskler makroekonomik göstergeler olduğundan diğer çalışmalardan farklı olarak makroekonomik değişkenler kullanılmıştır. Çalışmanın ana kütlesini Borsa İstanbul'da işlem gören imalat sektöründeki şirketler oluşturmaktadır. İmalat sektöründeki şirketler dışındaki finans şirketlerinin mali tabloları farkl1lık gösterdiğinden örnekleme dahil edilmemiştir. Çünkü finans sektöründeki şirketlerin aktif ve pasif hesapları imalat şirketlerinden oldukça farklıdır. Bu sektördeki şirketlerin ayrıca analiz edilmesi gerekmektedir. Çalışmanın önceki çalışmalardan bir farkı da imalat sektöründeki tüm şirketler üzerine yapılmasıdır. 2018 yılı itibariyle Borsa İstanbul imalat sanayisinde işlem gören 179 şirket vardır. Ancak bazı şirketler halka yeni açıldığından ve bazı şirketlerinde hisse senetleri borsada işlem görmediğinden örneklem 174 şirketten oluşmaktadır. 2008 yılında yaşanan küresel finansal krizin makroekonomik göstergeler üzerinde olumsuz etkileri olabildiğinden, çalışmada 2009 ve sonrasına ait veriler kullanılmıştır. Bazı şirketlerin 2010 yılından sonra kurulmasından dolayı verileri eksiktir. Bu nedenle uygulamada 174 şirketin 2009-2017 dönemine ait 8 y1llik verilerinden oluşan 1219 data kullanılmıştır. Uygulamada bazı şirketlerin verileri eksik olduğundan dengesiz panel veri yöntemi kullanılarak analiz yapılmıştır. Çalışmanın modelini oluşturan değişkenler, değişkenlerin türü ve kaynaklar Tablo 1'de verilmiştir.

Tablo 1: Değişkenler ve Veri Seti

\begin{tabular}{l|c|c|c}
\hline \hline Değişkenler & Nitelik & Frekans & Kaynak \\
\hline \hline Hisse Senedi Getirisi & Bağımlı & Yııllı & Borsa İstanbul \\
BIST 100 Endeksi & Bağımsız & Yıllık & Borsa İstanbul \\
Enflasyon Oranı & Bağımsız & Yı1lık & TCMB \\
Döviz Kuru & Bağımsız & Yıllık & TCMB \\
Faiz Oranı & Bağımsız & Yııllık & TCMB \\
Politik İstikrar İndeksi & Bağımsız & Yıllık & Dünya Bankası \\
\hline
\end{tabular}

Sistematik riskin hisse senedinin getiri üzerindeki etkisini tespit etmek için hisse senedinin cari yıl ile bir önceki yıl borsa fiyatının farkının hesaplanması gerekmektedir. Fiyatlar arasında fark hisse senedinin bir dönemlik getirisini veya kaybını göstermektedir. Böylece sistematik riskin hisse senedinin getirisi üzerindeki etkisi ortaya çıkmaktadır. Hisse senedinin getirisini hesaplamak için aşağıda verilen formül kullanılmıştır (Chun \& Ramasamy, 1989: 342):

$$
R_{i t}=\left(P_{i, t}-P_{i, t-1}\right) / P_{i, t-1}
$$

$R_{i t}$ hisse senedinin getirisini, $P_{i, t}$ hisse senedinin cari yıl fiyatını ve $P_{i, t-1}$ hisse senedinin bir önceki yıl fiyatını ifade etmektedir. Hisse senedinin cari yıl borsa fiyatı ile bir önceki yıl borsa fiyatının arasındaki farkın, hisse senedinin önceki yıl borsa fiyatına 
bölünmesiyle hisse senedinin bir yıllık getirisi (kaybı) hesaplanmaktadır. Ayrıca hisse senetlerinin getirileri hesaplanırken temettülerin de dâhil edilmesi gerekmektedir. Temettünün dâhil edilmesiyle aşağıda verilen formül ile hisse senedinin getirisi hesaplanmaktadır (Sharpe \& Cooper, 1972: 48):

$$
R_{i t}=\left(P_{i, t}+D-P_{i, t-1}\right) / P_{i, t-1}
$$

$D$ şirketlerin dağıttıkları temettüyü ifade etmekte olup dönem net karından veya geçmiş yıl karlarından dağıtılmaktadır. Borsa İstanbul'da işlem gören şirketlerin temettü tutarları ve temettü dağıtım sayısı önemsiz sayılacak kadar düşük tutarlarda olduğundan modele dâhil edilmemiştir. Çünkü çalışmada hisse senedi fiyatının sistematik riskten etkilenip etkilenmediği değerlendirilmek istenmiştir. Bu nedenle hisse senedinin fiyat değişiminin dolayısıyla getirisinin sistematik risk unsurlarından etkilenme durumunu incelemek için bağımlı değişken olarak modelde tanımlanmıştır.

Sistematik risk, piyasa riski, enflasyon riski, döviz kuru riski, faiz oranı riski ve politik riskten oluşmaktadır. Bu nedenle modelde yer alan bağımsız değişkenler sistematik riskin bileşenlerini oluşturmaktadır. Dolayısıyla söz konusu çalışmanın, önceki çalışmalardan farklı kılan, kullanılan değişkenlerin diğer çalışmalardan farklı olmasıdır. Önceki çalışmalarda yukarıda ifade edildiği üzere makroekonomik göstergeler kullanılarak sistematik risk incelenmemiştir. Genellikle literatürde sistematik risk unsuru olarak beta katsayısının kullanıldığ1 görülmektedir. $\mathrm{Bu}$ nedenlerden dolayı çalışmanın literatüre katkı sağlaması beklenmektedir. 2009 ve 2017 dönemine ait veriler, bir önceki yılın verileriyle karşıllaştırılarak yıllık baz da oransal değimler hesaplanmıştır. Modelde yer alan piyasa riski, pazar riski olarak da literatürde sıkça ifade edilmektedir. Borsa İstanbul'da işlem gören hisse senetlerinin Borsa endeksi ile doğrudan ilişkisi olduğu önceki çalışmalarda belirtildiğinden, pazar riski değişkeni olarak BIST 100 endeksi kullanılmıştır. İmalat sanayi endeksi verisi kullanılmak istenmiş, ancak Ulusal 100 endeksinin hisse senetlerinin fiyatları üzerinde daha etkili olduğundan kullanılmamıştır. Tandelilin (1997), Bodie (1976) ve Mandelker (1976) tarafından yapılan çalışmalarda finansal araçların getirilerinin enflasyondan etkilendiğini ifade etmiştir (Tandelilin, 1997: 101). Enflasyon değişkenini açıklamak için modelde TÜFE verisi kullanılmıştır (Nelson, 1976: 473). Cari yıldan, önceki yıl çıkarılmış, aradaki fark önceki yıla bölünerek enflasyondaki değişim hesaplanmıştır. Amerikan Doları ve Euro para birimlerinden oluşan döviz sepetindeki değişim, döviz kuru riskini ifade etmektedir. Francis (1991) faiz oranlarının hisse senedinin fiyatını etkilediğini ifade etmektedir. Faiz oranı, TCMB tarafından ilan edilen risksiz faiz oranıdır. Politik olayların ekonomi üzerindeki etkisini doğrudan ölçmek veya değerlendirmek pek mümkün değildir. Bu nedenle politik etkiyi ölçecek bir değişkene ihtiyaç vardır. Dünya Bankası, her ülkenin siyasi karar organlarında yaşanan siyasi olayların etkisi değerlendirmek için Politik istikrar indeksini oluşturmuştur. Politik istikrar indeksi Dünya Bankası tarafindan hesaplanmaktadır (Global Economy, 2018).

Hane, şirket, ülke gibi birden fazla yatay kesit ile birden fazla zaman kesitinin birleşmesiyle oluşan veri seti Panel Veri olarak ifade edilmektedir (Baltagi, 2005: 1). Birden fazla yatay kesite ait zaman serilerinin panel veri analizi dışında bir ekonometrik analizinin yapılması mümkün değildir. Panel veri regresyon analizinde aşağıda verilen formül kullanılmaktadır (Baltagi, 2005: 11):

$$
y_{i t}=\alpha+X^{\prime}{ }_{i t} \beta+u_{i t} \quad i=1, \ldots \ldots N ; t=1, \ldots \ldots T
$$

Denklemde verilen $\boldsymbol{i}$ şirket sayısını, $\boldsymbol{t}$ zaman serisini, $\boldsymbol{u}_{\boldsymbol{i}}$ hata katsayısını, $\boldsymbol{\alpha}$ sabit sayıyı, $\boldsymbol{X}^{\prime}{ }_{i \boldsymbol{t}}$, it'lerin gözlem sayısını ve $\boldsymbol{\beta}$ açıklayıcı değiş̧kenlerin katsayısını ifade etmektedir. Panel veri için çok sayıda analiz türü olup genel olarak sabit etkiler, rassal etkiler, havuzlanmış regresyon yöntemi ve rassal parametreler yöntemleri en çok kullanılan yöntemlerdir (Green, 2010: 386-387). Ayrica dengeli ve dengesiz panel veri modelleri de vardır (Baum, 2006: 46-51). 
Data setinde yatay kesitte bazı yıllarda eksik veri olması durumunda dengesiz panel veri analizi yapılmaktadır. Uygulamada bazı şirketlerin 2009 yılından sonra borsada işlem görmesinden dolayı dengesiz panel veri yöntemi tercih edilmiştir. Panel veri analizinde rassal etkiler ve sabit etkiler yöntemlerinden hangisinin kullanılacağına karar vermek için Hausman testi yapılmaktadır. Hausman testinden sonra panel veri en küçük kareler yöntemiyle analiz yapılarak bulgular değerlendirilmektedir.

\section{BULGULAR}

Analizden önce değişkenler arasındaki korelasyon ilişkisini test etmek için korelasyon testi yapılmıştır. Ardından modelde yer alan değişkenlerin tanımlayıcı istatistiklerine yer verilmiştir. Stata 15 paket programı ile analizler yapılmışıı. Panel veri analizinde rassal veya sabit etkiler yönteminden hangisinin kullanılacağına karar vermek için Hausman Testi yapılmıştır. Rassal etkiler en küçük kareler veya havuzlanmış regresyon analizinden hangisiyle yapılacağına karar vermek için ayrıca Bresch-Pagan testi yapılmıştır. Ön testler sonucunda panel veri rassal etkiler yöntemiyle analiz yapılması gerektiği tespit edilmiştir. Panel veri en küçük kareler yönteminde rassal etkiler yöntemiyle analiz yapılmış ve sonuçlar değerlendirilmiştir.

Tablo 2: Korelasyon Testi Sonuçları

\begin{tabular}{|c|c|c|c|c|c|c|c|}
\hline & & $\begin{array}{c}\text { H.S. } \\
\text { Getirisi }\end{array}$ & $\begin{array}{c}\text { BIST } \\
100 \\
\text { Endeks }\end{array}$ & Enflasyon & Döviz Kuru & $\begin{array}{c}\text { Faiz } \\
\text { Oranı }\end{array}$ & $\begin{array}{c}\text { Politik } \\
\text { İstikrar } \\
\text { Endeksi }\end{array}$ \\
\hline \multirow[t]{3}{*}{ H. S. Getirisi } & $\begin{array}{l}\text { Pearson } \\
\text { Correlation }\end{array}$ & 1 &, $296^{* * *}$ & ,015 &,$- 255^{* *}$ &,$- 129^{* *}$ &,$- 214^{* *}$ \\
\hline & Sig. (2-tailed) & &, 000 & ,592 &, 000 &, 000 &, 000 \\
\hline & $\mathrm{N}$ & 1219 & 1219 & 1219 & 1219 & 1219 & 1219 \\
\hline \multirow[t]{3}{*}{$\begin{array}{l}\text { BIST } 100 \\
\text { Endeks }\end{array}$} & $\begin{array}{l}\text { Pearson } \\
\text { Correlation }\end{array}$ &, $296^{* *}$ & 1 &,$- 129^{* *}$ &,$- 742^{* *}$ &,$- 344^{* *}$ &,$- 253^{* *}$ \\
\hline & Sig. (2-tailed) &, 000 & & ,000 &, 000 &, 000 &, 000 \\
\hline & $\mathrm{N}$ & 1219 & 1392 & 1392 & 1392 & 1392 & 1392 \\
\hline \multirow[t]{3}{*}{ Enflasyon } & $\begin{array}{l}\text { Pearson } \\
\text { Correlation }\end{array}$ &, 015 &,$- 129^{* *}$ & 1 &, $585^{* *}$ &, $458^{* *}$ &,$- 184^{* *}$ \\
\hline & Sig. (2-tailed) &, 592 & ,000 & &, 000 &, 000 &, 000 \\
\hline & $\mathrm{N}$ & 1219 & 1392 & 1392 & 1392 & 1392 & 1392 \\
\hline \multirow[t]{3}{*}{ Döviz Kuru } & $\begin{array}{l}\text { Pearson } \\
\text { Correlation }\end{array}$ &,$- 255^{* *}$ &,$- 742^{* *}$ &, $585^{* *}$ & 1 &, $234^{* *}$ &, $242^{* *}$ \\
\hline & Sig. (2-tailed) & ,000 &, 000 & ,000 & &, 000 & ,000 \\
\hline & $\mathrm{N}$ & 1219 & 1392 & 1392 & 1392 & 1392 & 1392 \\
\hline \multirow[t]{3}{*}{ Faiz Oranı } & $\begin{array}{l}\text { Pearson } \\
\text { Correlation }\end{array}$ &,$- 129^{* *}$ &,$- 344^{* *}$ &, $458^{* *}$ &, $234^{* *}$ & 1 &,$- 135^{* *}$ \\
\hline & Sig. (2-tailed) & ,000 & ,000 &, 000 &, 000 & & ,000 \\
\hline & $\mathrm{N}$ & 1219 & 1392 & 1392 & 1392 & 1392 & 1392 \\
\hline $\begin{array}{l}\text { Politik } \\
\text { İstikrar }\end{array}$ & $\begin{array}{l}\text { Pearson } \\
\text { Correlation }\end{array}$ &,$- 214^{* *}$ &,$- 253^{* *}$ &,$- 184^{* *}$ &, $242^{* *}$ &,$- 135^{* *}$ & 1 \\
\hline Endeksi & Sig. (2-tailed) &, 000 &, 000 &, 000 &, 000 &, 000 & \\
\hline & $\mathrm{N}$ & 1219 & 1392 & 1392 & 1392 & 1392 & 1392 \\
\hline
\end{tabular}


Tablo 2 Korelasyon testi sonuçları incelendiğinde hisse senedi fiyatının, bağımsız değişkenlerle korelasyon ilişkisinin olmadığı görülmektedir. Ancak BIST 100 Endeksi ile döviz kuru arasında negatif yönlü \%74,2 oranında; enflasyon ile döviz kuru arasında pozitif yönlü $\% 58,5$ oranında; faiz oranıla enflasyon arasında \%45,8 oranında korelasyon ilişkisi tespit edilmiştir. Makroekonomik değişkenlerin arasında korelasyon ilişkisinin olması beklenen bir durumdur. Ancak hisse senedi fiyatıyla bağımsız değişkenler arasında korelasyon ilişkisinin olmayışı modelin anlamlılık düzeyini artırması beklenmektedir. Modeldeki değişkenlerin tanımlayıcı istatistik sonuçları Tablo 3'de verilmiş̧tir.

Tablo 3: Modelin Tanımlayıcı İstatistikleri

\begin{tabular}{l|c|c|c|c|c}
\hline \hline Değişkenler & Gözlem & Minimum & Maksimum & Ortalama & Standart Sapma \\
\hline \hline Hisse Senedi Getirisi & 1219 & $-0,9200$ & 7,9800 & 0,2100 & 0,6394 \\
BIST 100 Endeksi & 1392 & $-0,2221$ & 0,5232 & 0,1358 & 0,2714 \\
Enflasyon Oranı & 1392 & 0,0616 & 0,1192 & 0,0848 & 0,0183 \\
Döviz Kuru & 1392 & $-0,0418$ & 0,2222 & 0,1130 & 0,1007 \\
Faiz Oranı & 1392 & $-0,7692$ & 2,3333 & 0,2967 & 0,9175 \\
Politik İstikrar Endeksi & 1392 & $-0,1280$ & 0,3670 & 0,0894 & 0,1960
\end{tabular}

2009-2017 döneminde hisse senedinin getirilerinde \%92 ile \%798 arasında bir değişim görülmektedir. Hisse senetleri 9 yıllık dönemde yıllık ortalama $\% 21$ oranında verim sağlamıştır. BIST 100 endeksindeki değişim -\%22 ile \%52 arasında gerçekleşmiştir. BIST 100 endeksindeki değişim ortalama \%13 oranında gerçekleşmiştir. Enflasyondaki değişimin ortalamas $\%$ \%,48'dir. Enflasyon oranında negatif bir eğilim olmamıştır. Döviz kurundaki değişim -\%4 ile \%22 arasında olduğu görülmektedir. Politik istikrar endeksinde ki değişim - $-\% 12$ ile \%36 aralığında gerçekleşmiştir.

Panel veri en küçük kareler yönteminde sabit etkiler mi yoksa rassal etkiler modellerinden hangisinin kullanılacağına karar vermek için Hausman testi yapılmıştır. Hausman testi hipotezleri aşağıda verilmiş olup test sonucu Tablo 4'de verilmiştir.

Ho: Rassal etkiler yöntemi kullanılmalıdır.

Ha: Sabit etkiler yöntemi kullanılmalıdır.

Tablo 4: Hausman Testi Sonuçları

\begin{tabular}{l|c|c|c|c}
\hline & (b) Sabit Etkiler & (B) Rassal Etkiler & b-B & S.E. \\
\hline BIST 100 Endeksi & $-0,2608487$ & $-0,2782313$ & 0,0173826 & 0,3181960 \\
Enflasyon Oran1 & 11,1609800 & 11,4638900 & $-0,3029118$ & 0,4458690 \\
Döviz Kuru & $-2,8909880$ & $-2,9559990$ & 0,0650110 & 0,1043123 \\
Faiz Oran1 & $-0,1744638$ & $-0,1778185$ & 0,0033546 & 0,0059444 \\
Politik İstikrar Endeksi & $-0,3324733$ & $-0,3227093$ & $-0,0097639$ & 0,0214505
\end{tabular}

Prob $>$ chi $2=0,9894$

Hausman testi p değeri $0,9894>0,05$ olduğundan Ha reddedilir ve Ho hipotezi kabul edilir. Test sonucuna göre panel veri analizinde rassal etkiler yönteminin kullanılması gerekmektedir. Hausman testi ile rassal etkiler yönteminde regresyon veya en küçük kareler yönteminin hangisinin kullanılacağına karar vermek içinde Breusch Pagan LM testi yapılmaktadır. Test için oluşturulan hipotezler aşağıda verilmiştir: 
Ho: Rassal etkiler yöntemi kullanılmalıdır.

Ha: En küçük kareler yöntemi kullanılmalıdır. verilmiştir.

Hipotezleri test etmek için Breusch ve Pagan Lagrangian Testi Sonucu Tablo 5' de

Tablo 5: Breusch ve Pagan Lagrangian Test Sonucu

\begin{tabular}{l|c|c}
\hline & Var & st = sqrt(var) \\
\hline fiyat & 0.408941 & 0.639485 \\
$\mathrm{e}$ & 0.357123 & 0.597598 \\
$\mathrm{u}$ & 0.0168229 & 0.1297031 \\
& & chibar2 $(01)=5.36$ \\
& & Prob $>$ chibar2 $=0.0103$
\end{tabular}

Breusch ve Pagan Lagrangian Test Sonucuna göre $p$ değeri 0,0103 olup değer $<0,05$ 'den küçük olduğundan ho hipotezi kabul edilmektedir. Dolayısıyla çalışmanın uygulamasında rassal etkiler yönteminin kullanılmasına karar verilmiştir.

Baltagi (2008) 20-30 y1llık zaman serisinin olduğu panel verilerde birim kök testi ile eşbütünleşme testi yapılabileceğini belirtmektedir. Stata 15 paket programında analiz için yeni nesil birim kök testlerinden Im-Peseran-Shin testi yapılmak istenmiş ancak yetersiz veri nedeniyle birim kök testi program tarafından yapılmamıştır. Dolayısıyla birim kök testi yapılamadığından eşbütünleşme ve panel koentegresyon testlerinin yapılması mümkün değildir. Panel veri rassal etkiler yöntemi analiz sonucu Tablo 6'da verilmiştir.

\section{Tablo 6: Panel Veri Analiz Sonucu}

\begin{tabular}{l|c|c|c|c}
$\begin{array}{l}\text { Gözlem sayısı=1219 } \\
\text { Grup sayısı174 }\end{array}$ & \multicolumn{3}{c}{$\begin{array}{c}\text { Wald chi2(5)=198,72 } \\
\text { Prob>Chi2=0,000 }\end{array}$} \\
\hline Hisse Senedi Getirisi & Katsayı & Standart Hata & $\mathbf{z}$ & P>z \\
\hline BIST 100 Endeksi & $-0,2782313$ & 0,1493796 & $-1,86$ & 0,063 \\
Enflasyon Oranı & 11,4638900 & 2,009785 & 5,70 & 0,000 \\
Döviz Kuru & $-2,9559990$ & 0,4895326 & $-6,04$ & 0,000 \\
Faiz Oranı & $-0,1778185$ & 0,0280831 & $-6,33$ & 0,000 \\
Politik İstikrar Endeksi & $-0,3227093$ & 0,0978323 & $-3,30$ & 0,001 \\
Sürekli değişken & $-0,3068430$ & 0,115059 & $-2,67$ & 0,008
\end{tabular}

Stata 15 paket programı çalışmanın modelini güçlü dengesiz panel veri modeli olarak tanımlamıştır. \%10 anlamlılık düzeyinde tüm değişkenler anlamlı çıkmıştır. \%5 anlamlılık düzeyinde ise sadece BIST 100 endeksi anlamsız çıkmıştır. \%1 anlamlılık düzeyinde ise yine BIST 100 Endeksi hariç diğer tüm değişkenler anlamlı çıkmıştır. Hisse senetlerinin getiri ile BIST 100 endeksi arasında negatif yönü \%27 oranında bir ilişki olması örneklemdeki imalat sektöründe faaliyet gösteren şirketlerin hisse senetlerinin endeks ile ters yönde hareket ettiğinin bir göstergesidir. Çünkü BISST 100 endeksinde yer alan şirketlerin bir kısmı imalat sektöründe faaliyet göstermektedir. BIST 100 endeksinin düşmesi imalat sektöründeki şirketlerin fiyatlarının yükselebileceğini ifade etmektedir. BİST 100 endeksi düştüğünde, imalat sektöründe faaliyet gösteren ve endekse yer almayan şirketlerin hisse senetlerinin satın alınması yatırımcının getiri elde etme olasılığını artıracağı düşünülmektedir. Yatırımcılar bunu dikkate alarak karar almalarının yararlı olacağı düşünülmektedir. 
Enflasyon oranı ile hisse senedi fiyatı arasında pozitif yönlü kuvvetli bir ilişki vardır. Enflasyon oranının yükselmesi hisse senedinin fiyatının da yükselmesine neden olabilmektedir. Oysaki hisse senedinin getirisiyle enflasyon arasında negatif yönlü bir ilişki olduğu tespit edilmiş olup, Francis (1991) tarafından yapılan çalışmanın sonucu bulguyu desteklemektedir. Makroekonomik göstergelerden biri olan enflasyon oranının yatırımcıların alım gücünü doğrudan etkilemektedir. Bu nedenle yatırımcılar enflasyondaki değişimi dikkate alarak hisse senetlerinden bekledikleri verimi değerlendirmektedir. Ayrıca hisse senetlerinin fiyatlarındaki değişim, enflasyon oranından negatif yönde etkilenebilmektedir. Şöyle ki, bir hisse senedinin cari fiyatının bir yıl önceki fiyatıyla aynı olduğunu varsayalım. Paranın Bir yıl önceki satın alma gücüyle alınan ürün veya hizmetler, bir yıl sonra enflasyon oranının yükselmesi sonucunda satın alınamadığında, hisse senetlerinin fiyatı nominal olarak aynı olsa da reel olarak değer kaybettiği görülmektedir. Yatırımcılar hisse senetlerinden bekledikleri verimi alamadıkları gibi enflasyondan dolayı portföylerinin reel satın alma değeri de düşebilmektedir. Bunun yanı sıra enflasyon şirketlerin finansal yapılarını da olumsuz yönde etkileyebilmektedir. Çünkü enflasyonun neden olduğu sistematik risk, şirketin reel piyasa değerini düşürebilmektedir. Ayrıca benzer bir durum döviz kurundaki değişimde de görülmektedir. Dövizde meydana gelen yükseliş, şirketin piyasa değerinin yabancı para birimi üzerinden düşmesine neden olabilmektedir.

Döviz kurundaki değişim hisse senetlerini fiyatı üzerinde etkili olmaktadır. Analiz sonucu incelendiğinde, döviz kuruyla hisse senedi getirisi arasında yüksek katsayılı negatif yönlü bir ilişkinin olduğu görülmektedir. Döviz kurunun ani ve hızlı yükselişi, menkul kıymetler borsalarından kaçışı beraberinde getirmektedir. Örneğin ülkemizde Mayıs 2019 tarihinde siyasi veya ekonomik faktörlerden dolayı döviz kuru, ani ve yukarı yönlü bir yükseliş göstermiştir. Buna paralel olarak Borsa İstanbul 100 endeksinde ani ve sert düşüşler görülmüştür. Literatürdeki çalışmalar incelendiğinde döviz kurundaki yükselişin, yatırımcıların uzun vadeli yatırım kararlarındaki pozisyonlarını değiştirerek, kısa vadeli yatırımlara yönelme eğiliminde olabildikleri görülmektedir. Böylece sert yükselişler ile birlikte döviz piyasasında talep artmakta ve döviz kurundaki yükseliş sistematik riski artırmaktadır. Ülkemizin ekonomi tarihi incelendiğinde döviz kurundaki sert yükselişler ile birlikte, borsa endeksinde sert düşüşler olduğu görülmektedir. $\mathrm{Bu}$ nedenle döviz kurundaki değişim, yatırımcıların hisse senetlerini satmasına neden olmakta, borsadan kaçışta hisse senetlerinin fiyatlarının düşmesine neden olmaktadır. Bazen yatırımcılar dövizden, menkul kıymet borsasındaki getiriden daha yüksek oranda getiri elde etmelerinden dolayı yatırımcıların yatırım araçlarında daha seçici davranmalarına neden olabilmektedir. Yatırımcılar, maalesef dövizi menkul kıymet borsalarına alternatif bir yatırım aracı görmektedir. Özellikle ülkemizde döviz kurundaki değişimin çok yüksek oranlarda olması, yatırımcıların riski dengelemek için para piyasası aracı olmasına rağmen portföylerinde dövize bulundurmalarına neden olabilmektedir.

Sermaye piyasalarında tahvil piyasalarının payı oldukça yüksektir. Faiz oranlarındaki yükseliş tahvil arz ve talebi üzerinde etkili olmaktadır. Çünkü tahvil uzun vadeli sabit getirisi olan alternatif bir finansal araçtır. Riski sevmeyen yatırımcılar tarafından tercih edilmektedir. Analizde faiz oranındaki yükselişin hisse senedinin fiyatını \%17 oranında düşürdüğü tespit edilmiştir. Faiz oranları yükseldiğinde, menkul kıymet borsalarındaki yatırımcılar, hisse senetlerini satarak para piyasasına yönelebilmektedir. Ülkemizde Borsa İstanbul'da faiz kararlarından olumlu veya olumsuz yönde etkilenebilmektedir. TCMB'nin faiz artırım kararı alması, BİST 100 endeksinin düşmesine neden olabilmektedir. Çünkü faiz artırım kararları sadece mevduat faizlerini değil, repo finansman bonosu ve devlet tahvili gibi faize dayalı finansal araçlara olan talebin artmasına neden olabilmektedir. Faize dayalı finansal araçların sabit getirisi olması ve risk taşımamaları, faiz oranlarının yükselmesiyle daha fazla tercih edilmelerine neden olabilmektedir. New York Borsasında yapılan bir çalışmada faiz oranıyla enflasyon oranının birbirine çok yakın olduğu ve reel getirinin oldukça düşük olduğu ifade 
edilmiştir (Ibbotson \& Sinquefield, 1976: 39-40). Ülkemizde enflasyon oranının yüksek olmas1, reel faiz oranlarının düşmesine neden olmaktadır.

Politik risk, ekonomiyi doğrudan etkilemektedir. Politik riski ölçmek için, Dünya Bankasının geliştirdiği Politik Istikrar Endeksi kullanılmıştır. Analiz sonuçlarına göre Politik İstikrar Endeksi ile hisse senedi fiyatı arasında negatif yönde \%32 oranında korelasyon ilişkisi olduğu tespit edilmiştir. Politik risk artığında, hisse senetlerinin fiyatında \%32'lik bir düşüş olmaktadır. Siyasi karar organlarının alacağı kararlar, ekonomi üzerinde doğrudan etkili olduğundan, siyasi belirsizlikler yatırımcıların borsadan çekilmelerine neden olabilmektedir. Örneğin Mart 2019'da İstanbul'da yapılan yerel seçimlerin yenilenme kararı, BIST 100 endeksini olumsuz yönde etkilemiş ve endeks değeri düşmüştür. Endeksin düşmesinde seçimin yenilenmesi kararı dışında birçok faktöründe etkili olmuş olabilir. Benzer bir sonuçta Tükenmez ve Kutay (2016) tarafından yapılan çalışmada politik riskin, menkul kıymet borsaları üzerinde etkisi olduğu ifade edilmiştir. Ağustos-Ekim 2019 döneminde Rahip Brunson davası olayında görüldüğü üzere politik olaylar, para ve sermaye piyasalarını doğrudan etkilemektedir. Küresel ve bölgesel politik istikrar sağlandığında ekonomide ve piyasalarda olumlu gelişmeler yaşanmaktadır. Politik riskin azalması, sermaye piyasasının gelişmesine ve büyümesine olumlu yönde katkı sağlaması beklenmektedir.

\section{SONUÇ}

Belirsizlik ve riskin olduğu piyasalarda yatırım kararları almak oldukça güçtür. Yatırımc1, portföy riskini düşürmek için çeşitli finansal araçlarla portföyü çeşitlendirse de, portföyden beklenen verimi elde edemeyebilir. Riskin portföy üzerindeki etkisini minimum düzeye indirmek için sistematik ve sistematik olmayan risk bileşenlerinin incelenmesi gerekmektedir. Sistematik olmayan risk, şirketten kaynaklandığ 1 için şirket yönetimi tarafından riskin düşürülmesi veya ortadan kaldırılması için önlem alınabilmektedir. Sistematik risk ise makroekonomik faktörlerden etkilendiğinden, yatırımcı veya şirket yönetimince herhangi bir müdahale söz konusu değildir. $\mathrm{Bu}$ nedenle sistematik risk, portföy riskini doğrudan etkilemektedir. Yatırımcılar sistematik risk unsurlarını inceleyerek riski minimize etme başarısı gösterebilirseler, portföyün toplam riski düşebilecektir. Böylece portföyden beklenen verim elde edilebilecektir. $\mathrm{Bu}$ nedenlerden dolayı sistematik risk faktörlerinin mikro bazda yapılmış çalışmalardan farklı olarak makroekonomik faktörler üzerinde yapılması literatüre katkı sağlaması açısından önem arz etmektedir.

$\mathrm{Bu}$ çalışmada sistematik riskin hisse senedi getirisi üzerine etkisi incelenmiştir. Enflasyon oranı ile hisse senedi fiyatı arasında pozitif yönlü kuvvetli bir ilişki vardır. Enflasyon makroekonomik göstergeler arasında alım gücünün tespitinde doğrudan etkili bir faktör olduğundan, yatırımcılar için önem arz etmektedir. Döviz kurundaki değişim hisse senetlerini fiyatı üzerinde etkili olmaktadır. Döviz kuruyla hisse senedi fiyatı arasında negatif yönde korelasyon ilişkisi tespit edilmiştir. Döviz kurundaki pozitif yönlü değişimin sonucunda yatırımcılar hisse senetlerini satmakta ve hisse senetlerinin fiyatı negatif yönde hareket etmektedir. Faiz oranlarındaki yükseliş tahvil arz ve talebi üzerinde etkili olmaktadır. Analiz sonucuna göre faiz oranındaki yükselişin hisse senedinin fiyatını $\% 17$ oranında düşürdüğü tespit edilmiştir. Dolayısıyla TCMB alacağı faiz artırım kararlarının menkul kıymet borsasını negatif yönde etkilemesi söz konusudur. Politik risk, ekonomiyi doğrudan etkilemektedir. Analiz sonuçlarına göre Politik İstikrar Endeksi ile hisse senedi fiyatı arasında negatif yönde \%32 oranında açıklamaktadır. Politik risk arttığında, imalat sektöründeki şirketlerin hisse senetlerinin fiyatı ortalama $\% 32$ oranında düşmektedir. Ülkemizde yaşanan siyasi kriz, gerilim veya olumsuz bir olay sonucunda Borsa İstanbul endekslerinin ani ve sert düşüşler göstererek tepki verdikleri geçmiş yıllarda görülmüştür. Politik risk, makroekonomik göstergeleri etkilemektedir. $\mathrm{Bu}$ 
nedenle politik riskin düşmesi ekonominin büyümesine ve gelişmesine katk1 sağlaması beklenmektedir.

Merkez Bankalarının risksiz faiz oranı kararlarının alındığı tarihten önce ve sonra, menkul kıymet borsası endeksi üzerindeki olumlu veya olumsuz etkisi vardır. Bundan sonra yapılacak çalışmalarda literatürde yapılmış çalışmalardan farklı olarak Merkez Bankalarının faiz oranı yükseltme veya düşürme kararlarının menkul kıymet borsaları endeksi üzerine etkisi incelenebilir. Literatürde yapılan çalışmalarda portföy riskini ölçmek için standart sapma, varyans ve kovaryans gibi istatistiki hesaplamaların yapıldığı görülmektedir. Sistematik risk ve sistematik olmayan riskin birlikte değerlendirileceği bir modelin geliştirilmesinin literatüre katkı sağlaması beklenmektedir. Ayrıca uluslararası hisse senetlerinden oluşan bir portföyün sistematik riskinin değerlendirilmesinin yatırımcılara faydalı olacağı düşünülmektedir.

\section{KAYNAKÇA}

Akıncı, U. C. (2007). Portföy yönetiminde sistematik siskin ölçülmesi ve IMKB için bir uygulama. Yüksek Lisans Tezi, Gazi Üniversitesi Sosyal Bilimler Enstitüsü İktisat Anabilim Dalı, Ankara.

Aksoy, A., ve Tanrı̈ven, C. (2007). Sermaye Piyasası Yatırım Araçları ve Analizi. Ankara: Gazi Kitabevi.

Arslan, Ç. (2013). The systematic risk determinants of tourism industry in Turkey. Master thesis, Eastern Mediterranean University Master of Science in Banking and Finance, North Cyprus.

Baltagi, B. H. (2005). Econometric analysis of panel data (Third Edition). England.: John Wiley\&Sons, Ltd.

Banz, R. W. (1981). The relationship between return and market value of common stocks. Journal of Financial Economics, 9 (1), 3-18.

Baum, C. F. (2006). An Introduction to Modern Econometrics Using Stata. Texas: A Stata Press Publication.

Beaver, W., ve Manegold, J. (1975). The Association Between Market-Determined and Accounting-Determined Measures of. The Journal of Financial and Quantitative Analysis, 10(2), 231-284.

Beaver, W., Kettler, P., \& Scholes, M. (1970). The Association between Market Determined and Accounting Determined Risk Measures. The Accounting Review, 45(4), 654-682.

Bowman, R. G. (1979). The Theoretical Relationship Between Systematic Risk and Financial (Accounting) Variables. The Journal of Finance, 34(3), 617-630.

Bozkurt, İ. (2014). İflas olasılığı ile Sistematik Risk İlişkisinin İncelenmesi ve Etkin İflas Göstergesi Modellerinin Tespiti: BİST'de Ampirik Bir Uygulama. Suleyman Demirel Üniversitesi İktisadi ve İdari Bilimler Fakültesi Dergisi, 19(4), 127-142.

Brigham, E. F., ve Houston, J. F. (2014). Fundamentals of Financial Management (Finansal Yönetimin Temelleri, Çev. Edi: Nevzat Aypek). Ankara: Nobel Yayınc1lık.

Cav, N. B. (2011). Sistematik riskin konaklama işletmelerinin karlılık oranları üzerindeki etkisinin ölçülmesi: Marmaris Altınyunus Turistik Tesisler A.Ş. örneği. Yüksek Lisans Tezi, Muğla Üniversitesi Sosyal Bilimler Enstitüsü İşletme Anabilim Dalı, Muğla.

Ceylan, A., ve Korkmaz, T. (2004). Sermaye Piyasast ve Menkul Değer Analizi. Bursa: Ekin Kİtabevi.

Chun, L. S., ve Ramasamy, M. (1989). Accounting variables as determinants of systematic risk in Malaysian common stocks. Asia Pacific Journal of Management, 6(2), 339-350.

Copeland, T., Koller, T., ve Murrin, J. (2000). Valuation Measuring and Managing Value of Companies(Third Edition). New York: McKinsey \& Company, Inc.

Çam, A. V. (2010). Ülke riskinin firma değeri üzerine etkisi: IMKB'ye kayıtl firmalar üzerine bir uygulama. Doktora Tezi, Selçuk Üniversitesi Sosyal Bilimler Enstitüsü İşletme Anabilim Dalı, Konya.

Dalgıç, C. (2011). Risk bileşenleri analizi: IMKB'de bir uygulama. Yüksek Lisans Tezi, Dokuz Eylül Üniversitesi SBE İşletme Anabilimdalı, İzmir.

Demir, B. (2010). Gelişmekte olan hisse senedi piyasalarının toplam ve sistematik risklerinin değerlendirilmesi. Yüsek Lisans Tezi, Çukurova Üniversitesi Sosyal Bilimler Enstitüsü İşletme Anabilimdalı, Adana. 
Derindere, S., ve Dizdarlar, H. I. (2008). Getiri Aralığının Sistematik Riskin Ölçüsü Olan Beta üzerine Etkileri: İMKB'de Bir Uygulama, Afyon Kocatepe Üniversitesi İ.̇̇.B.F. Dergisi, 10(1), 1-17.

Doğanay, M. (2016). Döviz Kuru Riski Yönetimine Sektörel Bir Yaklaşım. International Journal of Cultural and Social Studies (IntJCSS), 2(1), 149-164.

Ercan, M. K., ve Ban, Ü. (2008). Değere Dayalı İşletme Finansı Finansal Yönetim. Ankara: Gazi Kitabevi.

Eryiğit, C., ve Eryiğit, M. (2009). Temel Finansal Oranların Sistematik Riske Etkisi. İktisat, İsletme ve Finans Dergisi, Bilgesel Yayıncılık, 24(281), 60-76.

Fama, E. F. (1981). Stock Returns, Real Activity, Inflation, and Money. The American Economic Review, 71(4), 545565.

Fama, E. F., ve MacBeth, J. D. (1973). Risk return and equilibrium. some empirtcal tests. The Journal of Political Economy, 81(3), 607-636.

Francis, J. C. (1991). Investment: Analysis and Management. New York: McGrow Hill Inc.

Green, W. H. (2010). Econometric Analysis. England: Pearson Education Limited.

Gümüş, E. (2018). Sektörel bazda sistematik ve sistematik olmayan riskler ve bileşenleri, Borsa İstanbul uygulamast. Doktora Tezi, Anadolu Üniversitesi Sosyal Bilimler Enstitüsü İşletme Anabilim Dalı Finans Bilim Dalı, Eskişehir.

Hamada, R. S. (1972). The effect of the firm's capital structure on the systematic risk of common stocks. The Journal of Finance, 27(2), 435-452.

Ho, Y. K., Xu, Z., \& Yap, C. M. (2004). R\&D investment and systematic risk. Accounting and Finance, 44, $393-418$.

Horne, J. C., ve Wachowic, J. M. (2008). Fundamentals of Financial Management (13th Edition). England: Pearson Education Limited.

Ibbotson, R. G., ve Sinquefield, R. A. (1976). Stocks, bonds, bills, and inflation: year-by-year historical returns (19261974). The Journal of Business, 49(1), 11-47.

II, D. J. (1976). Sources of systematic risk in common stocks. The Journal of Business, 49(2), 173-188.

İskenderoğlu, Ö. (2012). Beta katsayısının tahmini: İstanbul Menkul Kıymetler Borsası üzerine bir uygulama. Ege Akademik Bakış, 12(1), 67-76.

Kaderli, Y., Petek, A., Doğaner, M., ve Babayiğit, G. (2013). Borsa İstanbul'daki Sektör Endekslerinin Pazar Endeksine Duyarlılı̆̆ının ve Sistematik Olmayan Risklerinin Ölçülmesi. Anadolu Üniversitesi Sosyal Bilimler Dergisi, 13(3), 55-64.

Karadeniz, E., Kandır, S. Y., \& İskenderoğlu, Ö. (2015). Sistematik riskin belirleyicileri: Borsa İstanbul turizm şirketleri üzerinde bir uygulama. Ç.Ü. Sosyal Bilimler Enstitüsü Dergisi, 24(1), 189-202.

Kara, S. (2016). Muhasebe Verilerine Dayalı Risk Ölçümü ile Sistematik Risk İlişkisi: Borsa İstanbul'da Bir Uygulama. Uluslararası Yönetim Íktisat ve Işsletme Dergisi, İCAFR 16 Özel Sayısı, 369-381.

Karan, M. B. (2004). Yatırım Analizi ve Portföy Yönetimi. Ankara: Gazi Kitabevi.

Kaya, A., Güngör, B., \& Özçomak, M. S. (2014). Politik risk yatırımcıların dikkate alması gereken bir riskmidir? Borsa İstanbul örneği. Gazi Üniversitesi İktisadi ve İdari Bilimler Fakültesi Dergisi, 16(1), 74-87.

Kaya, E. (2011). Türkiye'deki finansal sistemle uluslararası finansal sistemin sistematik risk açısından karşılaştırmalı analizi. Yüksek Lisans Tezi, Atatürk Üniversitesi Sosyal Bilimler Enstitüsü İşletme Anabilim Dalı, Erzurum.

Kırlı, M. (2006). Halka Açık Olmayan Şirketlerde Sistematik Risk Ölçütü Beta Katsayısının Tahmin Edilmesi. Yönetim ve Ekonomi: Celal Bayar İktisadi ve İdari Bilimler Fakültesi Dergisi, 13(1), 121-134.

Nelson, C. R. (1976). Inflation and Rates of Return on Common Stocks. The Journal of Finance, 31(2), 471-483.

Okka, O. (2009). Analitik Finansal Yönetim Teori ve Problemler. Ankara: Nobel Akademik Yayıncılık.

Okka, O. (2015). Finansal Yönetim Teori ve Çözümlü Problemler. Ankara: Nobel Akademik Yayıncılık.

Oral, İ. O., ve Yılmaz, C. (2017). Finansal ve politik risk endeksinin BİST Sınai Endeksi üzerine etkisi. Karadeniz Uluslararast Bilimsel Dergi, 33(33), 192-202.

Poyraz, E. (2011). Sistematik Riskin Konaklama İşletmelerinin Karlılık Oranları Üzerindeki Etkisinin Ölçülmesi (Marmaris Altınyunus Turistik Tesisleri A.Ş. Örneği). Dokuz Eylül Üniversitesi İktisadi ve İdari Bilimler Fakültesi Dergisi, 26(2), 67-75. 
Sharpe, W. F., ve Cooper, G. M. (1972). Risk-return classes of New York Stock Exchange common stocks, 19311967. Financial Analysts Journal, 28(2), 46-55.

Tandelilin, E. (1997). Determinants of systematic risk: experience of some Indonesian common stock. Kolola, 16(4), 101-114.

Tanrı̈ven, C., ve Aksoy, E. E. (2011). Sistematik riskin belirleyicileri: İMKB'de sektörel karşılaştırma. Muhasebe ve Finansman Dergisi, 51, 119-138.

Tepeli, Y. (2017). Halka açık olmayan anonim şirketlerde sistematik risk ölçütü Beta katsayısının tahmin edilmesi: turizm sektörü uygulaması. Muhasebe ve Finansman Dergisi(75), 155-170.

Tükenmez, N. M., ve Kutay, N. (2016). Ülke riskinin hisse senetleri getirileri üzerine etkisi: Türkiye ve Arjantin piyasaları için bir karşılaştırma. Atatürk Üniversitesi Sosyal Bilimler Enstitüsü Dergisi, 20(2), 631-645.

Uğurlu, M., Erdaş, M.L., ve Eroğlu, A. (2016). Portföy Yönetiminde Sistematik Riski Azaltacak Bir Doğrusal Programlama Model Önerisi. Çankırı Karatekin Üniversitesi İktisadi ve İdari Bilimler Fakültesi Dergisi, 6(1), 147174.

Ulusoy, T. (2008). Systematic risk and firm financial structure evidence from Istanbul Stock Exchange. The Business Review, Cambridge, 11(2), 226-231.

URL1. (2018). World Bank Data Catalog. https://datacatalog.worldbank.org/, Erişim Tarihi: 01.12.2018.

URL2. (2018). TCMB Elektronik Veri Dă̆ıtım Sistemi. https://evds2.tcmb.gov.tr/, Erişim Tarihi: 01.12.2018.

URL3. (2018). Borsa İstanbul Endeks Verileri. http://www.borsaistanbul.com/veriler/verileralt/hisse-senetleripiyasasi-verileri/endeks-verileri, Erişim Tarihi: 01.12.2018.

URL4. (2018). Yahoo Finance. https://finance.yahoo.com/, Erişim Tarihi: 01.12.2018.

Usta, Ö., ve Demireli, E. (2010). Risk bileşenleri analizi: İMKB'de bir uygulama. ZKÜ Sosyal Bilimler Dergisi, 6(12), 25-36.

Yalçıner, K. (2006). Risk ve Getiri Arasındaki Doğrusallı̆̆ın İMKB’de Analizi. Muhasebe ve Finansman Dergisi, 29, 182-189.

Zhang, X. F. (2006). Information Uncertainty and Stock Returns. The Journal of Finance, LX1(1), 105-136. 


\section{Extended Summary}

\section{Impact of Systematic Risk on Stock Return: An Application on Istanbul Stock Exchange}

Systematic risk affects adversely the returns of stocks. It is not possible to eliminate all of systematic risk. Investors want to reduce the non-systemic risk by diversifying the portfolio, thus reducing the total portfolio risk. For this reason, systematic risk is very important in investment decisions. The aim of this study is to examine the effect of systematic risk on stock return. In this study, systematic risk factors that affect the prices of stocks of manufacturing industry companies listed on Borsa Istanbul are determined.

The first study on measuring systematic risk was made by Markowitz (1952), who proposed modern portfolio management theory, Sharpe (1964), Lintner (1965), and Mossin (1966) conducted various studies on portfolio management using systematic risk ( $\mathrm{Ho}, \mathrm{Xu}, \&$ Yap, 2004: 395). Since most of the securities in the portfolio move in the same direction as market returns, it is not possible to eliminate them by differentiation method (Okka, 2015: 407). It is not possible to eliminate the risks, as some of the risks arise from macroeconomic factors, not the company itself. Therefore, systematic risk cannot be eliminated by diversification (Karan, 2004: 157). However, unless the correlation between the securities in the portfolio is perfect, the risk of the portfolio can be reduced by differentiating the securities (Okka, 2015: 407). Thus, the standard deviation of each security by the differentiation of securities and the average of standard deviations of the securities constituting the portfolio reduce the risk of the portfolio (Brigham \& Houston, 2014: 269).

There are also various risks arising from the company itself, which are referred to as nonsystematic risks and can be eliminated by differentiation. Risks constituting the portfolio are divided into two as systematic and non-systematic risks in the literature (Okka, 2009: 233). Systematic risk is the risk that affects all securities in the market or in the stock market at the same time and in the same direction. Systematic risk affects all financial markets and securities at the same time (Oral \& Y1lmaz, 2017: 194). It is not possible for companies to reduce, eliminate or avoid this risk as long as they continue to exist in that country. Although systematic risk is classified into different categories in the literature, interest rate, inflation risk, market risk, exchange rate risk and political risk are analyzed in five categories.

In the studies conducted in the literature, the effect of systematic risk on stock returns has been examined by using Beta coefficient, accounting data, various ratios and index returns. Unlike the studies in the literature, micro data was not used, and analyses were made with macroeconomic indicators. The main mass of the study consists of manufacturing companies listed on Borsa Istanbul. As of 2018, there are 179 companies listed on the Borsa Istanbul manufacturing industry. However, the sample consists of 174 companies, as some companies have recently opened to the public and some companies have not traded on the stock exchange. Since the global financial crisis in 2008 may have negative effects on macroeconomic indicators, the data for 2009 and onwards were used in the study. Since some companies were established after 2010, their data is incomplete. For this reason, 1219 data consisting of 8 years' data of 174 companies for the period of 2009-2017 were used in the application. Unbalanced panel data method has been used since there are companies with missing data. 2009-2017 period data of the 174 companies operating in the Borsa İstanbul manufacturing industry sector were used in analysis. When the studies in the literature are examined, they are seen that the financial statements data and beta coefficient of the companies are frequently used. Unlike previous studies, the panel data analysis was performed by using BIST 100 index variables as model price, interest rate, inflation rate, exchange rate, political risk index, market risk variable. The 
data set formed by the combination of more than one horizontal cross-section and more than one-time cross-section such as household, company and country is referred to as panel data (Baltagi, 2005: 1). It is not possible to perform an econometric analysis of time series belonging to more than one horizontal section other than panel data analysis. It was made correlation test, Hausman Test and panel data test in implementation, respectively.

When the correlation test result is analyzed, it is seen that the stock price has no correlation with independent variables. Stocks yielded an average annual yield of $21 \%$ in the 9year period. The change in the exchange rate was between $4 \%$ and $22 \%$. There is a strong positive relationship between inflation rate and stock price. The change in the exchange rate affects the price of stocks. In the analysis, it was determined that the increase in the interest rate decreased the stock price by $17 \%$. According to the analysis results, there is a negative correlation between Political Stability Index and stock price of $32 \%$.

The effect of systematic risk on stock returns is examined. There is a strong positive relationship between inflation rate and stock price. Inflation is an important factor for investors in determining the purchasing power among macroeconomic indicators. The change in the exchange rate affects the price of stocks. A negative correlation was found between exchange rate and stock price. With the change in the exchange rate, investors sell their stocks and the prices of stocks move negatively. The rise in interest rates has an impact on the bond supply and demand. According to the results of the analysis, it is found that the increase in the interest rate decreased the stock price by $17 \%$. Therefore, the CBRT's decision to raise interest rates can have been a negative impact on the stock exchange. It is waited that political risk directly affects the economy. According to the analysis results, there is a negative correlation between Political Stability Index and stock price of $32 \%$. There is a $32 \%$ decrease in the price of stocks when the political risk increases. After the political events in our country, it has been seen in the past years that the stock market index showed sharp and sharp decreases. It contributes to the growth and development of the economy in order to reduce the political risk. 
Optimum Journal of Economics and Management Sciences, Vo1. 7, No. 1- http://dergipark.gov.trloptimum

Dayl - Impact of Systematic Risk on Stock Return: An Application on Istanbul Stock Exchange 